\title{
BLACK BIBLICAL HERMENEUTICS AND IDEOLOGICALLY AWARE READING OF TEXTS
}

\author{
EB Farisani \\ Old Testament \& Ancient Near Eastern Studies \\ University of South Africa
}

\begin{abstract}
This paper examines the role of Black Biblical hermeneutics in the development and propagation of Black theology and then goes on to argue for a sociological analysis of biblical texts as a preferred methodological approach for Black theology to effectively unearth the ideologies imbedded in biblical texts. Accordingly, this paper proposes a sociological analysis of Biblical texts. The above stated focus of this paper will be done in the following four stages. First, this paper provides a brief sketch of the emergence of Black theology and the role of Black biblical hermeneutics in support of the struggle of Black people against oppression in South Africa. Second, the paper discusses Mosala's critique of Black theology and Black biblical hermeneutics. Third, the paper discusses reconstruction theology and its ideologically unaware reading of biblical texts. Finally, the paper spells out the role of Black Biblical hermeneutics in the current post-Apartheid South Africa. This is where the contribution of a sociological analysis/reading of biblical text will be spelt out as the preferred methodological approach for Black theology in the current post Apartheid context.
\end{abstract}

Key Words: Black Theology, Reconstruction Theology, Ideology, Hermeneutics

\section{Introduction}

Kai Nielsen has defined an ideology as follows:

A system of ideas, theories, beliefs, attitudes, norms, and social practices that (a) is characteristic of a class or other primary social group in a class society and that (b) serves principally the interests of a class, typically a class in that society, or other primary social group while, typically at least, putting itself forward as answering the interests of the whole of the society ${ }^{1}$

In South Africa certain scholars used the biblical text to support an apartheid ideology which systematically oppressed and dehumanised black people. In response, Black theology also used the bible as a weapon in the struggle of black people against the apartheid ideology. This paper examines the role of Black Biblical hermeneutics in the development and propagation of Black theology and then goes on to argue for a sociological analysis of biblical texts as a preferred methodological approach for Black theology to effectively unearth the ideologies imbedded in biblical texts.

Accordingly, this paper proposes a sociological analysis of Biblical texts. Thus, a sociological reading/analysis argues that Black theology will have to continue to take seriously, in its theological discourse in the post-Apartheid South Africa, the fact that each and every text in the Bible is the product of its socio-historical context. And that, in order to

1 Nielsen, K 1989. Marxism and the Moral Point of View. Boulder and London: Westview Press, page 33. 
effectively use any text, without it further oppressing and silencing the previously silenced and marginalised black people, the text's ideology has to be subjected to a rigorous sociological analysis, so as to de-ideologise it. The above stated focus of this paper will be done in the following four stages. First, this paper provides a brief historical overview of the emergence of Black theology and the role of Black biblical hermeneutics in support of the struggle of Black people against oppression in South Africa. Second, the paper discusses Mosala's critique of Black theology and Black biblical hermeneutics. Third, the paper discusses reconstruction theology and its ideologically unaware reading of biblical texts. And, finally, the paper spells out the role of Black Biblical hermeneutics in the current post-Apartheid South Africa. This is where the contribution of a sociological analysis/reading of biblical text will be spelt out as the preferred methodological approach for Black theology in the current post Apartheid context.

\section{Black Theology: A Brief Historical Overview}

Motlhabi is concerned that black theologians have 'gone into recess'. ${ }^{2}$ He observes that "there have been no major seminars or conferences on Black Theology in South Africa since 1996. Nor have there been any significant or groundbreaking publications since then... It is regrettable ... in the light of the new social issues that require urgent theological, especially theological-ethical, reflection and response". 3

However, it is important to note that Tinyiko Maluleke has remained one of the faithful champions of Black Theology today. Through his well researched articles he has and continues to dialogue with African and Black theologians across all disciplines including amongst others: Inculturation theologies, Shift of gravity theologies, Translation theologies, Reconstruction theologies, Women theologies, Reading with theologies, African Independent Church theologies, South African Black theologies ${ }^{4}$ etc.

Motlhabi reminds us that the emergence of Black Theology in South Africa "was the seeming irrelevance of the white church in ministering to the physic-spiritual needs of black people. Not only was the church seen as a colonial church, it was also seen as a status quo church. On the one hand, its chief aim was originally to mister solely to the spiritual needs of white people-from the very advent of colonialism to the time of the total disinheritance of black people in the country. On the other hand, while successive white governments increasingly added to the oppression and woes of black people, the church served largely to placate them and to keep them in line with the demands of white interests, greed and

Motlhabi, M 2008. African Theology/ Black Theology in South Africa: Looking Back, Moving On, page x.

Motlhabi, M 2008. African Theology/Black Theology in South Africa: Looking Back, Moving On. Pretoria: UNISA, page 13 .

4 Maluleke, TS 1994. The Proposal for a Theology of Reconstruction: A Critical Appraisal. Missionalia 22 (3), pp. 245-258.

- 1994. Review of Vila-Vicencio, C 1992. A Theology of Reconstruction: A Nation-Building and Human Rights. Cape Town: David Philip. Missionalia. 22 (2), pp. 186-188.

- 1996. Recent Developments in the Christian Theologies of Africa. Missionalia 24 (3), pp. 472-473.

- 1997a. Truth, National Unity and Reconciliation in South Africa: Aspects of the Emerging Theological Agenda. Missionalia 25 (1), pp. 59-86.

- 1997b. Dealing lightly with the wound of my people? The TRC process in Theological Perspective. Missionalia 25:3 (November) pp. 324-343.

- 1999. Truth and reconciliation discourse: A black theological Evaluation, in Cochrane, J, et al (eds.) pp. 101-113. 
capitalism". Accordingly, the African Initiated Churches emerged in the late 1800s as a form of early protest against white domination and exploitation in the church. ${ }^{6}$

Black theology emerged almost a century after the first African Initiated Churches. For Motlhabi, this theology was aimed "largely at filling this gap and searching aggressively for theological answers to the problem of white domination and oppression. In this way it rejected white theology and its interpretation of the Gospel, life and reality. It challenged the church's complacency with the status quo and its justifications of its complacency".

Bonganjalo Goba, a participant in early Black Theology in South Africa, talks about theology, black identity and the black Christian dilemma:

There was a feeling amongst those of us who were involved [in early Black Theology] that somehow we had experienced ... a theological schizophrenia. We were split... Part of our formation was terribly white, influenced by the western theology... And there was another side to that in that we had our own [black] agenda which had never been addressed. So that the issue had to do with the identity crisis which we confronted ${ }^{8}$

Motlhabi informs us of a shift in Black theology from solely focussing on racism to also focus on issues of class and gender discriminations "as cardinal sins of the same magnitude as racism". 9 This stance is clearly reflected in a collection of essays presented at two conferences in $1983 .^{10}$

\section{Sources of Black Theology}

Bongajalo Goba used four basic sources for Black Theology, namely the Bible, African tradition, black experience and critical theory. ${ }^{11}$ Itumeleng Mosala also employed four sources for his historical materialist Black Theology of Liberation. First, African Traditional Religions teach Black Theology the significance of operating communally in the struggle. Mosala places/traces the indigenous religions into two historical periods, namely primitive African communal society and African feudal socio-economic relations. ${ }^{12}$ The second source of Mosala's Black Theology is culture. Here, Mosala employs a cultural category derived from the everyday black experience. Thus, he argues that "Black Theology ... will have to rediscover black working class and poor peasant culture in order to find for itself a materialist hermeneutical starting point". ${ }^{13}$ Mosala's third source is the African Independent Churches. ${ }^{14}$ And, his fourth source is the Bible.

\footnotetext{
Motlhabi, M 2008. African Theology/Black Theology in South Africa: Looking Back, Moving On, page 2.

Motlhabi, M 2008. African Theology/Black Theology in South Africa: Looking Back, Moving On, page 2.

Motlhabi, M 2008. African Theology/Black Theology in South Africa: Looking Back, Moving On, page 2.

Hopkins, DN 1989. Black Theology USA and South Africa: Politics, Culture, and Liberation.

Maryknoll:Orbis, page 29.

9 Motlhabi, M 2008. African Theology/Black Theology in South Africa: Looking Back, Moving On, page 2.

10 Mosala, IJ and Tlhagale, B 1975. The Unquestionable Right to be Free. Johannesburg: Skotaville.

11 Goba, B 1988. Agenda for Black Theology in South Africa: Hermeneutics for Social Change. Johannesburg: Skotaville, pp. 53-55. See also Hopkins, DN 1989. Black Theology USA and South Africa: Politics, Culture, and Liberation. Maryknoll:Orbis, page 124.

12 Hopkins, DN 1989. Black Theology USA and South Africa: Politics, Culture, and Liberation. Maryknoll:Orbis, page 131.

13 Mosala, IJ 1986. The use of the Bible in Black Theology in Mosala, IJ and Tlhagale, B. The Unquestionable Right to be Free. Johannesburg: Skotaville, page 185; Mosala, IJ 1985. African Independent Churches: A study in the Socio-Theological Protest , in Villa-Vicencio, C and de Gruchy, J, Resistance and Hope: South African Essays in Honour of Beyers Naude. Grand Rapids: Eerdmans, page 109; Mosala, IJ 1986. Social
} 
It is important to note that for the majority of black theologians four sources were employed in their quest for a Black Theology in South Africa. However, these sources were never interpreted in the same manner by all black theologians. The focus of this paper is on how the fourth source, namely the Bible, was used in a quest for a Black Theology and further on how an ideologically aware reading of biblical texts could strengthen our black theological discourse in South Africa today.

\section{Mosala's Ideologically Aware Black Biblical Hermeneutics}

How does Mosala describe ideology? He sees ideology thus:

It is rather a harmonization of contradictions in such a way that the class interests of one group are universalized and made acceptable to other classes. ${ }^{15}$

Mosala goes on to argue that making scientific sense of the ideological condition of a text means knowing the text in a way in which it is incapable of knowing itself. In this regard Eagleton argues that:

The task of criticism, then, is not to situate itself within the same space as the text, allowing it to speak or completing what it necessarily leaves unsaid. On the contrary, its function is to install itself in the very incompleteness of the work in order to theorise itto explain the ideological necessity of those 'not-saids' which constitute the very principle of its identity. Its objects are the unconsciousness of the work-that of which is not, and cannot be, aware. ${ }^{16}$

Moreover, Mosala critiques both the historical-critical method, the social scientific method and Black Theology's uncritical exegetical starting point, which expresses itself in the notion that the Bible is the revealed 'word of God'. ${ }^{17}$ Accordingly, Mosala argues that the notion of the Bible as 'the revealed Word of God' leads to a false notion of the Bible as nonideological. He maintains that such a notion can cause political paralysis in the oppressed people who read it:

An approach to the study or appropriation of the Bible that begins with the theological notion of the Bible as the Word of God, therefore, presupposes a hermeneutical epistemology for which truth is not historical, cultural, or economic. For such an epistemology the Word of God is pre-established. The political, cultural, economic, or historical relevance of this Word of God comes out of its capacity to be applied to the various facets of human life, and in this case of black human life. Its relevance does not issue out of its very character as a historical, cultural, political, or economic product. ${ }^{18}$

Scientific Approaches to the Bible: One Step Forward, Two Steps Backward, Journal of Theology for Southern Africa (June 1986), page 30.

14 Mosala, IJ 1986. Black Theology in South Africa and North America: Prospects for the future; Building of Aliances. Unpulished paper presented at the Black Theology Conference: Dialogue Between USA and South Africa, Union Theological Seminary, New York (1-3 December 1986), page 7; Mosala IJ, African Independent Churches, pages 110-11; Hopkins, DN 1989. Black Theology USA and South Africa: Politics, Culture, and Liberation. Maryknoll: Orbis, page 131.

15 Mosala, IJ 1989. Biblical Hermeneutics and Black Theology in South Africa. Michigan: Grand Rapids, pp. 118-119.

16 In Mosala, IJ 1989. Biblical Hermeneutics and Black Theology in South Africa. Michigan: Grand Rapids, page 119 .

17 Mosala, IJ 1989. Biblical Hermeneutics and Black Theology in South Africa. Michigan: Grand Rapids, page 6.

18 Mosala, IJ 1989. Biblical Hermeneutics and Black Theology in South Africa. Michigan: Grand Rapids, pp. 19-20. 
Mosala argues that the historical-critical method, the social scientific method, and Black Theology:

...have failed to recognize the ideological character in the texts. These methods have not been able to sufficiently address issues of ideology, race, gender, class, and politics in their application to the Bible. ${ }^{19}$

Thus, Mosala proposes a new exegetical starting point, since "The social, cultural, political, and economic world of the black working class and peasantry constitutes the only valid hermeneutical starting point for a Black Theology of liberation". ${ }^{20}$ He bases his hermeneutics on the key concept of struggle:

I argue that the category of struggle provides the lens for reading the text in a liberating fashion as well as the codes for unlocking the possibilities and limitation of the biblical texts. $^{21}$

So Mosala sees the category of "the black struggle, from pre-colonial times to the present, as representing an important hermeneutical factor":22

I propose that, in this appropriation of black history and culture for purposes of appropriating biblical texts, the category of struggle will serve as a critical grid. ${ }^{23}$

The category of struggle becomes an important hermeneutical factor not only in one's reading of his or her history and culture but also in one's understanding of the history, nature, ideology, and agenda of the biblical texts. ${ }^{24}$

Consequently, a biblical hermeneutics of liberation, using the same tool of struggle as was used to interrogate the readers' history, culture, and ideology, must now address the question of the material conditions that constitute the sites of the struggles that produced the biblical texts. ${ }^{25}$

The above analysis of Mosala does not mean that he rejects totally the biblical text. He gives the reason for his appropriation of the biblical tradition in another article in which he identifies two sources of Black Theology as 'the biblical and the African roots' ${ }^{26}$ However we must, Mosala argues, employ a socio-historical materialist method of interpretation to identify the ideology of the text. Explaining his materialistic reading of the Bible, he further argues:

I used a materialist method to delineate the struggles inherent in black history and culture; I will use a similar method to connect us with the struggles behind and in the text of the Bible. ${ }^{27}$

19 Mosala, IJ 1989. Biblical Hermeneutics and Black Theology in South Africa. Michigan: Grand Rapids, page 7.

20 Mosala, IJ 1986. Ethics of the Economic Principles: Church and Secular Investments, in Tlhagale, B \& Mosala, IJ (eds.) 1986:119-129. See also Mosala, IJ 1989. Biblical Hermeneutics and Black Theology in South Africa. Michigan: Grand Rapids, page 21.

21 Mosala, IJ 1989. Biblical Hermeneutics and Black Theology in South Africa. Michigan: Grand Rapids, page 8.

22 Mosala, IJ 1989. Biblical Hermeneutics and Black Theology in South Africa. Michigan: Grand Rapids, page 123 .

23 Mosala, IJ 1989. Biblical Hermeneutics and Black Theology in South Africa. Michigan: Grand Rapids, page 12.

24 Mosala, IJ 1989. Biblical Hermeneutics and Black Theology in South Africa. Michigan: Grand Rapids, page 9.

25 Mosala, IJ 1989. Biblical Hermeneutics and Black Theology in South Africa. Michigan: Grand Rapids, page 9.

26 Mosala, IJ 1986. Ethics of the Economic Principles: Church and Secular Investments, in Tlhagale, B \& Mosala, IJ, page 119. See also Burden, JJ 1993. Social Science and Recent Trends in Old Testament Research: Its Relevance for South African Old Testament Scholarship. Old Testament Essays 6, page 222.

27 Mosala, IJ 1989. Biblical Hermeneutics and Black Theology in South Africa, page 103. 
In order to unearth the ideology of the text, Mosala believes that the exegete must identify the social, cultural, class, gender and racial issues that are at work in the biblical text:

What historical point is reflected by the discursive practice this text represents? What are the social, cultural, class, gender, and racial issues at work in this text? What is the ideological-spiritual agenda of the text, that is, how does the text itself seek to be understood $?^{28}$

Mosala sees a two-way dialogue between black history and the Bible:

Thus black culture and history as hermeneutical factors in Black Theology in South Africa ask questions of the biblical text that seek to establish ties with struggles for liberation in the biblical communities. Similarly, the liberating aspects of the biblical discourses interrogate black culture and history in the light of the values and goals of struggling classes in biblical communities. ${ }^{29}$

Therefore, the task of biblical hermeneutics of liberation is as follows:

To go behind the dominant discourses to the discourse of oppressed communities in order to link up with kindred struggles. The task now facing a Black Theology of liberation is to enable black people to use the Bible to get the land back and to get the land back without losing the Bible. In order for this to happen, Black Theology must employ the progressive aspects of black history and culture to liberate the Bible so that the Bible may liberate black people. That is the hermeneutical dialectic. ${ }^{30}$

Mosala's work is important, in that it helps us to see that the biblical text is ideological. This is also our view in this paper. We will argue later that the biblical text has a particular ideological inclination. We will also show in the next subsection that the observation by Mosala, that the biblical text is not neutral, but has a particular ideology, is something the advocates of reconstruction theology (Villa-Vicencio, Mugambi, Karamaga etc) have failed to identify and have not seriously taken into consideration when setting forth a theology of reconstruction based on Ezra-Nehemiah and other biblical texts. Furthermore, Mosala's hermeneutic, like the hermeneutic proposed by this paper, is black, in that it takes seriously the black experience (culture, history etc) of colonial exploitation and the role of capitalism in our context.

\section{Reconstruction Theology's Ideologically Unaware Hermeneutics}

Jesse Mugambi introduces reconstruction as a new paradigm for African Christian theology in Africa. He explores the role of Christian theology in the social reconstruction of Africa. He argues that the reconstruction theme is evoked partly by the changes that have taken place during the 1960s, 1970s and 1980s, and partly by the emergence of the 'New World Order' after the end of colonialism, apartheid and the cold war. ${ }^{31}$

Mugambi sees the 1990s as a very difficult decade for peoples in all nations of the world. The Old Secular Order has passed away suddenly, he argues, and the new World Order is hardly here with us. Mugambi views the arrival of the New World Order as posing a challenge for us to be very creative and innovative. ${ }^{32}$ Mugambi, ${ }^{33}$ like Villa-Vicencio ${ }^{34}$

\footnotetext{
Mosala, IJ 1989. Biblical Hermeneutics and Black Theology in South Africa, pp. 34-5.

Mosala, IJ 1989. Biblical Hermeneutics and Black Theology in South Africa, page 152.

Mosala, IJ 1989. Biblical Hermeneutics and Black Theology in South Africa, page 153.

Mugambi, JNK 1995. From Liberation to Reconstruction. Nairobi: East Africa Educational Publishers, page x.

Mugambi, JNK 1995. From Liberation to Reconstruction. page 18.
} 
before him, argues for a shift of paradigms from liberation to reconstruction theology. His concern is that in the recent past, liberation and inculturation have been taken as the most 'basic concepts for innovative African Christian theology'. 35

Mugambi believes that after the abolition of apartheid, the 'metaphor' of the Exodus, which has been mainly used by liberation theologians, has become 'inapplicable and irelevant'. ${ }^{36}$ Using Ezra-Nehemiah as a model for a reconstruction theology, Mugambi declares that:

After the Babylonian exile, a new nation was reconstructed under the direction of Ezra and Nehemiah. The role of Nehemiah as the director of the reconstruction project is lucidly explained in the book bearing his name. Nehemiah becomes the central text of the new theological paradigm in African Christian theology, as a logical development from the Exodus motif. ${ }^{37}$

Accordingly, Mugambi sees the figure of Nehemiah not only as an exemplary character, but also as a leader who represents the aspiration and contradiction of Africa's social reconstruction at this time in history. ${ }^{38}$

\section{Critiques of Mugambi's Reconstruction Theology}

Several scholars have critiqued both Mugambi's reconstruction theology and his use of Ezra-Nehemiah in its quest. For a detailed critique of Mugambi's reconstruction theology by Maluleke see some of his works. ${ }^{39}$ Maluleke correctly observes that though Mugambi offers a few biblical and socio-political justifications for his reconstruction paradigm, these are never fully developed. Thus, Maluleke observes further that Mugambi’s socio-political argumentation for the need for social. ${ }^{40}$ Furthermore, Maluleke is concerned that Mugambi does not even acknowledge or engage the biblical hermeneutic developed in the liberation paradigm (e.g. Itumeleng Mosala's work on biblical hermeneutics). ${ }^{41}$

Maluleke's above critique of Mugambi's reconstruction theology sets the scene for Musa Dube's critique of both Mugambi's reconstruction theology and his use of EzraNehemiah. Firstly, Musa Dube is very critical of Mugambi's call for us to move from liberation to reconstruction theology. Dube argues that as a postcolonial feminist, she does not see liberation and reconstruction as frameworks that should be separated, as she does not think that liberation is something that we need to transcend. ${ }^{42}$

33 Mugambi, JNK 1995. From Liberation to Reconstruction. See also Mugambi, JNK 1999. Foreword, in Getui, MN and Obeng, EA (eds.) 1999:i-iv. Refer also to Mugambi, JNK 2003. Christian Theology and Social Reconstruction. Nairobi: Acton.

34 Villa-Vicencio, C 1992. A theology of Reconstruction. Cape Town: David Phillip. See also Villa-Vicencio, C 1992. Learning to say a theological "yes". A new challenge for the church in South Africa. Word and Action/ Woord en Daad, 32 (388):11-18. Villa-Vicencio, C 1993. Beyond Liberation Theology: A new theology for South Africa. Challenge Magazine, pp. 24-25.

35 Mugambi, JNK 1995. From Liberation to Reconstruction, page 2.

36 Mugambi, JNK 1995. From Liberation to Reconstruction, page 165.

37 Mugambi, JNK 1995. From Liberation to Reconstruction, page 13.

38 Mugambi, JNK 1999. Foreword, in Getui, MN and Obeng, EA (eds.) pp. iii-iv.

39 Maluleke TS 1996. Recent Developments in the Christian Theologies of Africa. Missionalia 24 (3), page 473.

$40 \quad$ Maluleke TS 1996. Recent Developments in the Christian Theologies of Africa. Missionalia 24 (3), page 473.

41 Maluleke TS 1996. Recent Developments in the Christian Theologies of Africa, page 473.

42 Dube, M 2002. Jesse Mugambi is Calling Us to Move from Liberation to Reconstruction! A Postcolonial Feminist Response. A paper delivered at a symposium at the University of South Africa, page 4. 
Thus, she argues:

As women in various cultures and religions, our liberation and rights are hardly guarantied. It is within the parameters of the struggle for liberation that we are able to call and ask for our rights and for reconstructive efforts that embrace and affirm women and men. ${ }^{43}$

In her view, liberation should provide the values that guide our reconstruction.

Secondly, she suggests that a call From Liberation to Reconstruction could have been better entitled, 'No Liberation without Reconstruction.' Alternatively, she argues, it could have been called 'Reconstruction for Liberation'. 44

Furthermore, Dube charges that Mugambi's reconstruction theology has a minimal commitment to gender justice.

And, finally, Dube also argues that the Ezra-Nehemiah story is not only a colonizing story, it is also gender oppressive:

The leader of the community in the reconstruction is male and he calls for what I can call some form of 'ethnic cleansing.' Ezra-Nehemiah urges all Israelite men who had married foreign women to divorce them, and they do. ${ }^{45}$

Musa Dube's above critique of Mugambi's reconstruction theology sets the scene for our critique of both Mugambi's reconstruction theology and his use of Ezra-Nehemiah.

I have also critiqued Mugambi's ideologically unaware use of Ezra-Nehemiah. ${ }^{46}$ Firstly, Mugambi, like Villa-Vicencio and other reconstructionists, does not seem to have read the text of Ezra-Nehemiah carefully. They do not seem to identify or examine critically the ideology behind the conflict between the returned exiles and the am haaretz. Secondly, they also suppresses the voice of the am haaretz, in that they neither identify nor analyse critically the ideology within the text, an ideology which is biased against the am haaretz. Thirdly, by using the reconstruction theme in Ezra-Nehemiah without isolating the ideological agenda of the text and identifying the group which is dominant in the text, Mugambi et al have inadvertently identified reconstruction as that which is driven by the returned exiles at the exclusion of the am haaretz. Such a reading of the text is insensitive to the plight of the am haaretz. Finally, like Villa-Vicencio, though Mugambi argues for a postexilic metaphor as a basis for his reconstruction theology, he hardly develops or unpacks what and how these metaphors could be used effectively. Rather, he includes in his postexilic metaphors different texts from different socio-political contexts without doing a sociological analysis of any of them. ${ }^{47}$

43 Dube, M 2002. Jesse Mugambi is calling us to Move from Liberation to Reconstruction! A Postcolonial Feminist Response. A paper delivered at a symposium at the University of South Africa, page 4.

44 Dube, M 2002. Jesse Mugambi is calling us to Move from Liberation to Reconstruction! A Postcolonial Feminist Response. A paper delivered at a symposium at the University of South Africa, page 6.

45 Dube, M 2002. Jesse Mugambi is calling us to Move from Liberation to Reconstruction! A Postcolonial Feminist Response. A paper delivered at a symposium at the University of South Africa, page 13.

46 Farisani, E 2002. The ideologically biased use of Ezra-Nehemiah in a quest for an African theology of reconstruction. Old Testament Essays. 15/3 pp. 628-646; Farisani, E 2003. The use of Ezra-Nehemiah in a quest for an African theology of reconstruction. Journal of Theology for Southern Africa. 116, pp. 27-50.

47 Farisani, E 2002. The ideologically biased use of Ezra-Nehemiah in a quest for an African theology of reconstruction. Old Testament Essays. 15/3, pp. 628-646; Farisani, E 2003. The use of Ezra-Nehemiah in a quest for an African theology of reconstruction. Journal of Theology for Southern Africa. 116, pp. 27-50. 


\section{Ideologically Aware Reading of Biblical Text}

The Ezra-Nehemiah text has been used by Jesse Mugambi and others in a quest for a theology of reconstruction. The way these African scholars have used Ezra-Nehemiah undermines their basic call for a theology which aims at addressing the needs and plight of the poor and the marginalised in Africa. This is precisely because they appropriate the EzraNehemiah text without engaging with the text in any depth. By not so doing, these scholars have failed to identify an ideology prevalent in the Ezra-Nehemiah text, an ideology which is biased in favour of the returned exiles, but biased against the am haaretz. ${ }^{48}$ I have elsewhere shown how such a sociological analysis of texts in crucial in identifying ideologies which are embedded within biblical texts. ${ }^{49}$

What, then, is the contribution of a sociological analysis of the biblical text to Black theology? A sociological reading of any biblical text's contribution to the project of Black theology is on the theological level. First, it warns against any uncritical reading of the Biblical text. By uncritical reading, we refer to any reading of the Bible which does not engage in an in-depth manner with the text. Any uncritical reading of the Biblical text tends to further oppress and sideline the poor and marginalised by appropriating the ideologically undifferentiated Biblical text as the 'revealed word of God' ${ }^{50}$ Instead of empowering the poor and marginalised, an uncritical reading of the text disempowers and weakens them ${ }^{51}$. Thus, a sociological analysis argues that Black Theology will have to take seriously, in its theological discourses in South Africa, the fact that each and every text in the Bible is the product of its socio-historical context. And that, in order to effectively use any text in the Black Theology project, without it further oppressing and silencing the already silenced and marginalised poor, the text's ideology has to be subjected to a rigorous sociological analysis, so as to de-ideologise it. ${ }^{52}$

Second, a sociological reading of the text goes further, to read any biblical text 'against the grain'. By so doing, such an analysis hopes that in appropriating any biblical text in addressing the class, race and gender issues in South Africa, black theologians will be sensitive to the voices and needs of all stakeholders in taking up this theological task in Africa. ${ }^{53}$

48 Farisani, E 2002. The ideologically biased use of Ezra-Nehemiah in a quest for an African theology of reconstruction. Old Testament Essays. 15/3, pp. 628-646; Farisani, E 2003. The use of Ezra-Nehemiah in a quest for an African theology of reconstruction. Journal of Theology for Southern Africa. 116, pp. 27-50.

49 Farisani, E 2002. The ideologically biased use of Ezra-Nehemiah in a quest for an African theology of reconstruction. Old Testament Essays. 15/3, 2002:628-646; Farisani, E 2003. The use of Ezra-Nehemiah in a quest for an African theology of reconstruction. Journal of Theology for Southern Africa. 116, pp. 27-50.

50 Mosala, IJ 1989. Biblical Hermeneutics and Black Theology in South Africa.

51 Farisani, E 2002. The ideologically biased use of Ezra-Nehemiah in a quest for an African theology of reconstruction. Old Testament Essays. 15/3, pp. 628-646; Farisani, E 2003. The use of Ezra-Nehemiah in a quest for an African theology of reconstruction. Journal of Theology for Southern Africa. 116, pp. 27-50.

52 Farisani, E 2002. The ideologically biased use of Ezra-Nehemiah in a quest for an African theology of reconstruction. Old Testament Essays. 15/3, pp. 628-646; Farisani, E 2003. The use of Ezra-Nehemiah in a quest for an African theology of reconstruction. Journal of Theology for Southern Africa. 116, pp. 27-50.

53 Farisani, E 2002. The ideologically biased use of Ezra-Nehemiah in a quest for an African theology of reconstruction. Old Testament Essays. 15/3, pp. 628-646; Farisani, E 2003. The use of Ezra-Nehemiah in a quest for an African theology of reconstruction. Journal of Theology for Southern Africa. 116, pp. 27-50. 


\section{Conclusion}

Let us briefly summarise our findings in this paper.

Mosala's critique of Black theology and other theologies raises several issues which are relevant to this paper. First, there is a need for a Black reading of the Bible, which will take seriously the black context in its theologising. Mosala uses several sources for his hermeneutics, including the Bible and the black experience. Secondly, Mosala recognises that not every text in the Bible is liberatory, or neutral. Rather it is coloured with the ideology of the author. This observation by Mosala is something the advocates of reconstruction theology (Villa-Vicencio, Mugambi, Karamaga etc.) have not seriously taken into consideration when setting forth a theology of reconstruction based on Ezra-Nehemiah and other reconstructionists.

Our study of the text of Ezra-Nehemiah takes seriously the fact that this text is not neutral; it is embedded within an ideological world of its author, which suppresses and oppresses the voice of the marginalised group, namely the am haaretz. Having argued for the identification and analysis of ideologies in biblical texts, this paper proposed an ideologically aware reading of biblical texts. Linked to this is the third point, namely, if black biblical hermeneutics has to have an impact in post-Apartheid South Africa, it does not only have to relate the text as is to the black context, it must also de-ideologies that particular text in the first place. For an unideologised reading may be counterproductive, in that instead of supporting and advancing the cause of the black and marginalised, such a reading may further marginalise them by further enslaving them with the 'revealed word of God'.

\section{BIBLIOGRAPHY}

Burden, JJ 1993. Social Science and Recent Trends in Old Testament Research: Its Relevance for South African Old Testament Scholarship. Old Testament Essays 6, 205-232.

Dube, M 2002. Jesse Mugambi is calling us to Move From Liberation to Reconstruction! A Postcolonial Feminist Response. A paper delivered at a symposium at the University of South Africa, 1-16.

Farisani, E 2002. The ideologically biased use of Ezra-Nehemiah in a quest for an African theology of reconstruction. Old Testament Essays. 15/3, pp. 628-646.

Farisani, E 2003. The use of Ezra-Nehemiah in a quest for an African theology of reconstruction. Journal of Theology for Southern Africa. 116, pp. 27-50.

Farisani, EB 2004. The composition and date of Ezra-Nehemiah. Old Testament Essays. 17/2, pp. 208-230.

Farisani, EB 2004. A sociological analysis of Israelites in Babylonian exile. Old Testament Essays. $17 / 3$, pp. $380-388$.

Farisani, EB 2006. The Third Return of the Babylonian Exiles to Palestine. Old Testament Essays 19/3, pp. 1162-1177.

Farisani, EB 2008. The Israelites in Palestine during the Babylonian exile. Old Testament Essays 21/1, pp. 69-88.

Getui, MN, \& Obeng, EA (eds.) 1999. Theology of Reconstruction. Nairobi: Acton.

Goba, B 1988. Agenda for Black Theology in South Africa: Hermeneutics for Social Change. Johannesburg: Skotaville. 
Hopkins, DN 1989. Black Theology USA and South Africa: Politics, Culture, and Liberation. Maryknoll: Orbis.

Ka Mana, 2002. Christians and Churches of Africa Envisioning the Future. Regnum Africa: Ghana.

Karamaga, A 1997. A theology of Reconstruction, in Mugambi, JNK (ed.), pp. 190-191.

Maluleke, TS 1994. The Proposal for a Theology of Reconstruction: A Critical Appraisal. Missionalia 22 (3), pp. 245-258.

--- 1994. Review of Vila-Vicencio, C 1992. A Theology of Reconstruction: A NationBuilding and Human Rights. Cape Town: David Philip. Missionalia. 22 (2), pp. 186-188.

--- 1996. Recent Developments in the Christian Theologies of Africa. Missionalia 24 (3), pp. 472-473.

--- 1997a. Truth, National Unity and Reconciliation in South Africa: Aspects of the Emerging Theological Agenda. Missionalia 25 (1), pp. 59-86.

--- 1997b. Dealing lightly with the wound of my people? The TRC process in Theological Perspective. Missionalia 25:3 (November), pp. 324-343.

--- 1999. Truth and reconciliation discourse: A black theological Evaluation, in Cochrane, $\mathrm{J}$ et al (eds.), pp. 101-113.

Mosala, IJ 1986. Ethics of the Economic Principles: Church and Secular Investments, in Tlhagale, B \& Mosala, IJ, (eds.), pp. 119-129.

Mosala, IJ 1985. African Independent Churches: A study in the Socio-Theological Protest, in Villa-Vicencio, C and de Gruchy, J, Resistance and Hope: South African Essays in honour of Beyers Naude. Grand Rapids: Eerdmans.

Mosala, IJ 1986. The use of the Bible in Black Theology in Mosala, IJ and Tlhagale, B. The Unquestionable Right to be Free. Johannesburg: Skotaville, page 185.

Mosala, IJ 1986. Social Scientific Approaches to the Bible: One Step Forward, Two Steps Backward, Journal of Theology for Southern Africa.

Mosala, IJ 1986. Black Theology in South Africa and North America: Prospects for the future; Building of Aliances. Unpublished paper presented at the Black Theology Conference: Dialogue between USA and South Africa, Union Theological Seminary, New York.

Mosala, IJ \& Tlhagale, B 1987. The Unquestionable Right to be Free. Johannesburg: Skotaville.

--- 1987. The meaning of reconciliation: A black perspective. Journal of theology for Southern Africa 59, pp. 19-25.

Mosala, IJ 1989. Biblical Hermeneutics and Black Theology in South Africa. Michigan: Grand Rapids.

Motlhabi, M 2008. African Theology/Black Theology in South Africa: Looking Back, Moving On. Pretoria: UNISA.

Mugambi, JNK 1995. From Liberation to Reconstruction. Nairobi: East Africa Educational Publishers.

Mugambi, JNK 1999. Foreword, in Getui, MN and Obeng, EA (eds.), pp. i-iv.

Mugambi, JNK 2003. Christian Theology and Social Reconstruction. Nairobi: Acton. 
Nielsen, K 1989. Marxism and the Moral Point of View. Boulder and London: Westview Press.

Tlhagale, B, \& Mosala, IJ (eds.) 1986. Hammering swords into ploughshares: Essays in honour of Archbishop Mpilo Desmond Tutu. Johannesburg: Skotaville.

Villa-Vicencio, C 1992. A theology of Reconstruction. Cape Town: David Phillip.

--- 1992. Learning to say a theological 'yes'. A new challenge for the Church in South Africa. Word and Action/Woord en Daad, 32 (388):11-18.

--- 1993. Beyond Liberation Theology: A new theology for South Africa. Challenge Magazine, 24-25. 